\title{
MICRONUCLEUS LEVELS AND SISTER CHROMATIDE EXCHANGE FREQUENCIES IN BORON EXPOSED AND CONTROL INDIVIDUALS
}

\author{
BORA MARUZ KALAN BİREYLERDE VE KONTROL BIREYLERINNDE \\ MIKKROÇEKİRDEK DÜZEYLERİ VE KARDEŞ KROMATİD DEĞİŞİM \\ FREKANSLARI
}

\author{
Zuhal UÇKUN ${ }^{1}$, Aylin ÜSTÜNDAĞ ${ }^{1}$, Mehmet KORKMAZ ${ }^{2}$, Yalçın DUYDU ${ }^{1}$ \\ ${ }^{1}$ Ankara Üniversitesi, Eczacılık Fakültesi, Farmasötik Toksikoloji Anabilim Dalı, \\ 06100 Tandoğan-Ankara, TÜRKIYE \\ ${ }^{2}$ Celal Bayar Üniversitesi Tıp Fakültesi, Tıbbi Biyoloji Anabilim Dalı, \\ Manisa, TÜRKIYE
}

\begin{abstract}
The aim of the study was to investigate the genotoxic effects in boron exposed humans. SCE frequencies in boron exposed and control group were 7,28 $\pm 1,60$ and 9,50 $\pm 1,83$, respectively. SCE frequencies in boron exposed individuals were significantly lower than the controls (Mann Whitney U- test, $p<0,05)$. The MN values in boron exposed individuals were also lower than the control group. Nevertheless the difference between boron exposed humans and controls was statistically not significant $\left(\chi^{2}\right.$ test, $\left.p>0,05\right)$. In spite of the statistical insignificancy, lower $M N$ values were also observed in boron exposed group. When these results were taken into consideration the decrease in SCE and MN values might be a reflection of a protective effect of boron aganist DNA damage. However this suggestion surely needs further investigation.
\end{abstract}

Key words: Boron, Genotoxicity of boron, Lymphocytes, Micronucleus, Sister chromatide exchange. 


\section{ÖZET}

Çalışmanın amacı bor maruziyetinin insanlar üzerindeki genotoksik etkilerini araştırmaktı. Bora maruz kalan bireylerde SCE frekanslarl (7,28 \pm 1,60) kontrol grubuna $(9,50 \pm 1,83)$ göre önemli oranda düşüktü (Mann Whitney U- test, $p<0,05$ ). Benzer düşüş bora maruz kalan bireylerin MN değerlerinde de gözlenmiştir. Ancak maruz grup $(9,81 \pm 1,94)$ ile kontrol grubun $(20,32 \pm 3,98)$ MN değerleri arasındaki farklılık istatistiksel olarak anlamlı değildir ( $\chi^{2}$ testi, $\left.p>0,05\right)$. Bu sonuçlar borun oluşabilecek genetik hasarlara karşı koruyucu bir etkisinin olabileceğini düşündürmektedir. Ancak daha fazla çalışmaların yapılmasl gerekmektedir.

Anahtar kelimeler: Bor, Bor Genotoksitesi, Lenfosit, Mikroçekirdek, Kardeş kromatid değişimi.

\section{GİRIŞ}

Kimyasal sembolü B ile tanımlanan bor elementi periyodik sistemin III. grubunun başında olup bu grubun metal olmayan yegane elementidir. Atom numarası 5 ve atom ağırlığı 10,81 olan bor elementi kütle numaraları $10(10 \mathrm{~B} \% 19,8)$ ve $11(11 \mathrm{~B} \% 80,2)$ olan iki kararlı izotoptan oluşmaktadır (1).

Doğada serbest olarak, başka bir deyişle elementel olarak bulunmayan bor elementi daima oksijene bağlı halde genellikle borat formu şeklinde bulunan bor elementi (2) yer kabuğunda, atmosferde, denizde, toprakta, kömürde, yeraltı ve yerüstü sularında ve sedimentlerde yüksek oranda bulunmaktadır $(3,4)$. Yeryüzünde geniş bir alana yayılmış halde bulunan bor elementi doğada değişime uğramaz ve parçalanmaz. Ancak çevre koşullarına bağlı olarak (nem, pH vb.) spesifik formlarına dönüşebilmektedir (1). Doğal olarak bor toprakta 5 - 150 ppm (2) yerkabuğunda ortalama $10 \mathrm{ppm}$, deniz suyunda 0,5 - 9,6 ppm arasında olup ortalama $4.6 \mathrm{ppm}$, tatl sularda $<0,01-1,5 \mathrm{ppm}$ (1) havada ise $<0,5-80 \mathrm{ng} / \mathrm{m}^{3}$ arasinda (ortalama $20 \mathrm{ng} / \mathrm{m}^{3}$ ) bulunur (5).

İnsanlar tarafindan oral yolla alınan borun hemen hemen tamamı gastrointestinal yoldan hizlı bir şekilde absorbe edilir (5). Absorbe edilen bor, vücut sıvılarında pasif difüzyonla çok hızlı bir şekilde dağılır (5). Bor oksijenle yaptığı bağ çok güçlüdür (B-O). Bu bağın kopması için ancak laboratuar koşulları altında sağlanabilecek çok yüksek bir enerjiye $(523 \mathrm{kj} / \mathrm{mol})$ gereksinim duyulduğundan borat bileşiklerinin insanlarda ve hayvanlarda metabolize olma olasıllğ çok düşüktür $(4,6)$. Bor başta idrar olmak üzere ter, solunum, salya ve feçesle atılmaktadır. Bor, vücuda hangi yolla alınırsa alınsın \% 92 -96' sı alındıktan 96 saat sonra hiç değişmeden idrarla atılmakta (1) ve $3-7$ gün içinde de vücuttan tamamen elimine olmaktadır (2). 
Bor; kalsiyum, fosfor, vitamin $\mathrm{D}$, magnezyum, molibden, alüminyum gibi çeşitli mikronutrientlerin metabolizmasında regulatör bir rol oynamaktadır. Yapılan çalışmalar borun insan ve hayvanlar için diyetle alınabilen esansiyel bir komponent olduğunu (7) ve insanların günde en az $1 \mathrm{mg}$ bor almaları gerektiğini göstermektedir (8). The Food and Nutrition Board of The Institute of Medicine (2001) ve The Institute of Medicine (IOM, 2002) tarafindan da borun yetişkinler tarafından alınabilecek üst sınırını $20 \mathrm{mg} /$ gün olarak açıklamışlardır $(9,10)$.

İnsanlarda ve hayvanlarda borik asit kısa sürede vücuttan uzaklaştırıldığından dolayı toksik etkisini yüksek miktarda maruz kalındığında gösterir $(7,11)$. Borun tek doz olarak alındığında öldürücü olma olasıllğı oldukça düşüktür. Ancak bireylerde kan dolaşım bozukluğu ve böbrek yetmezliği olması durumunda yüksek dozda bor alındıktan kısa bir süre sonra ölüm görülebilir (7).

Borun genotoksik etkilerini araştırmak amacıyla yapılmış birçok standart genotoksisite ve mutajenite testi vardır (Çizelge 1). Uygulanan standart genotoksisite ve mutajenite testleriyle borik asidin bakteriyel ve memeli sistemlerde mutajenik ve genotoksik bir etkisi olmadığ ulaşılmaktadır. Ancak bugüne kadar bor maruziyetinin insanlar üzerindeki genotoksik etkilerinin yer aldığı bir çalışmaya rastlanmamıştır. Çalışmaların büyük bir çoğunluğu in vitro koşullarda ve hücre kültürlerinde gerçekleştirilmiştir. Bora maruz kalan kişilerle yapılmış araştırma sonuçları oldukça sınırlıdır.

Çizelge 1. Borun genotoksik etkileri ile ilgili yapılmış çalışmalar.

\begin{tabular}{|c|c|c|c|c|c|}
\hline Kimyasal & Test & Test Ortamı & $\begin{array}{c}\text { KC S-9 } \\
\text { Fraksiyonu }\end{array}$ & Sonuç & Kaynak \\
\hline Borik Asit & Mutasyon testi & $\begin{array}{l}\text { Escherischia Coli } \\
\text { Sd-4 }\end{array}$ & & "negatif" & 12 \\
\hline Borik Asit & Mutasyon testi & $\begin{array}{l}\text { Salmonella } \\
\text { Typhimurium }\end{array}$ & $+/-$ & "negatif" & 13 \\
\hline Borik Asit & $\begin{array}{c}\text { Unscheduled DNA } \\
\text { sentezi } \\
\text { indüksiyonu }\end{array}$ & $\begin{array}{l}\text { F344 Siçan } \\
\text { hepatositleri }\end{array}$ & & "negatif" & 14 \\
\hline Borik Asit & $\begin{array}{l}\text { Fare Lenfoma } \\
\text { mutasyon testi }\end{array}$ & $\begin{array}{l}\text { L5178Y Fare } \\
\text { lenfoma hücreleri }\end{array}$ & $+/-$ & "negatif" & 13 \\
\hline Borik Asit & $\begin{array}{l}\text { Kromozom hasar } \\
\text { testi }\end{array}$ & CHO Hücrelerinde & $+/-$ & "negatif" & 13 \\
\hline Borik Asit & KKD Frekans1 & CHO Hücrelerinde & $+/-$ & “negatif” & 13 \\
\hline Borik Asit & MÇ testi & $\begin{array}{l}\text { Swiss-Webster } \\
\text { Farelerinde, Kemik } \\
\text { iliği eritrositlerinde }\end{array}$ & & "negatif" & 15 \\
\hline
\end{tabular}


Yapılan bu çalışmada ülkemizde bor bakımından oldukça zengin alanlarda yaşayan insanlardan alınan kan örneklerinde borun genotoksik etkisi araştııılmıştır. Bu amaçla yapılan biyoizleme çalışmalarında lenfosit hücrelerindeki DNA hasarı kardeş kromatid değişimi (KKD) ve mikroçekirdek (MÇ) yöntemleri kullanılarak belirlenmiştir.

\section{MATERYAL VE YÖNTEM}

\section{Kan Örneklerinin Sağlanması}

Çalı̧̧mada kullanılan kan örnekleri Balıkesir Valiliği'nden alınan izin ile (31.12.2004, 15/21776) Balıkesir'in Bigadiç bölgesinde yaşayan insanlardan alınmıştır. İskele ve yöresindeki içme ve kullanma sularında yüksek oranda bor $(1,55$ - 20,8 mg / $)$ bulunmaktadır (16). Bu bölgeden alınan kan örnekleri bora maruz kalan kişileri temsil etmektedir $(n=38)$. Bademli yöresindeki içme ve kullanma sularındaki bor konsantrasyonları çok düşüktür $(0,07-0,2 \mathrm{mg} / \mathrm{l})$ (16). Bu bölgede yaşayan insanlardan alınan kan örnekleri de kontrol grubunu temsil etmektedir $(n=38)$. Tüm kanlar analiz edilene kadar (en çok 24 saat) heparinli tüplerde ve $+4^{\circ} \mathrm{C}^{\prime} \mathrm{de}$ bekletilmiştir.

\section{Kardeş Kromatid Değişim (KKD) Analizi}

KKD analizi için, heparinli tüplerde bulunan kandan $0.3 \mathrm{ml}$ alınarak steril tüplere aktarıldı ve üzerlerine \% 12 fetal calf serum (Biological Industries, Ashrat, İsrail) ve $0.25 \mathrm{ml} \mathrm{L}$ - glutaminpenisilin-streptomisin (Sigma) içermekte olan $2.5 \mathrm{ml}$ RPMI 1640 (Sigma) medyum ilave edildi. Lenfositlerin bölünmesini uyarmak amaciyla $56 \mu 1$ fitohemaglütinin ilave edildi ve $37{ }^{0} \mathrm{C}$ 'de 24 saat süreyle inkübe edildi. 24 süre sonunda $3 \mu 1$ 5-bromo-2-deoksiüridin (BrdU, Sigma) ilave edildi ve $37{ }^{0} \mathrm{C}$ 'deki inkübatöre kaldırıldı. 68. saatte ise $75 \mu \mathrm{l}$ kolşisin ( $0.4 \mu \mathrm{g} / \mathrm{ml}$, Sigma) ilave edildi ve yeniden $37{ }^{\circ} \mathrm{C}^{\prime}$ deki inkübatöre kaldırıldı. 72. saatte tüpler inkübatörden alındı ve 2000 rpm'de 15 dakika santrifüj edildi. Tüpten üst faz $0.5 \mathrm{ml}$ oluncaya kadar pellet atıldı ve $37{ }^{0} \mathrm{C}$ 'de bekletilerek 1sıtılan $0.075 \mathrm{M} \mathrm{KCl}$ çözeltisi ile 5 ml'ye tamamland1. $37{ }^{0} \mathrm{C}$ 'deki inkübatörde 15 dakika bekletildi. Ardından 2000 rpm'de 15 dakika santrifüj edildi. Tüpte üst faz $1 \mathrm{ml}$ oluncaya kadar pellet atıldı. Soğuk carnoy's çözeltisi (3:1 oranında metanol ve glasiyel asetik asit) ile hacim 5 ml'ye tamamlandı. 12-24 saat buzdolabında bekletilerek 1. fiksasyon tamamlandı. Bu işlem $2 \mathrm{kez}$ tekrarlandı. Son aşamada $1.5 \mathrm{ml}$ üst faz bırakıldı. Hücre süspansiyonu önceden deterjanla yıkanmış temiz lamlara yaklaşık olarak 1 metre mesafeden damlatıldı ve 1şıktan koruyarak kurumaya 
bırakıld1. Lamlar kuruduktan sonra Hoechst-Giemsa yöntemine (18) göre boyand1. Her kan numunesine karş1lık gelen lamlarda 50 adet II. metafaz hücresinde KKD sayıldı. 50 adet II. metafaz hücresindeki kırıkların ortalaması alındı. Proliferasyon indeksini (PRI) bulmak için I. metafaz (MI), II. metafaz (MII) ve III. metafaz (MIII) hücreleri toplam 100 hücre olacak şekilde sayıldı.

PRI= (1xMI+2xMII+3xMIII)/100 formülüne göre PRI hesaplandı.

\section{Mikroçekirdek (MÇ) Analizi}

MÇ analizi için, heparinli tüplerde bulunan kandan $0.3 \mathrm{ml}$ alınarak steril tüplere aktarıldı ve üzerlerine \% 12 fetal calf serum (Biological Industries, Ashrat, İsrail) ve $0.25 \mathrm{ml}$ L- glutaminpenisilin-streptomisin (Sigma) içermekte olan $2.5 \mathrm{ml}$ RPMI 1640 (Sigma) medyum ilave edildi. Lenfositlerin bölünmesini stimule etmek amacıyla $56 \mu$ fitohemaglütinin ilave edildi ve $37^{\circ} \mathrm{C}$ 'deki inkübatöre kaldırılarak 72 saatlik inkübasyon başlatıldı. 44 saat sonra $15 \mu 1$ sitokalasin -B (Sigma) ilave edildi ve $37{ }^{\circ} \mathrm{C}^{\prime}$ deki inkübatöre kaldırıld1. 72. saatte 2000 rpm'de 15 dakika santrifüj edildi. Tüpte üst fazdan $0.5 \mathrm{ml}$ oluncaya kadar pellet atıldı ve $37{ }^{\circ} \mathrm{C}^{\prime}$ de bekletilerek isitılan $0.075 \mathrm{M} \mathrm{KCl}$ çözeltisi ile 5 ml'ye tamamlandı. $37{ }^{\circ} \mathrm{C}^{\prime}$ deki inkübatörde 15 dakika bekletildi. Ardından 2000 rpm'de 15 dakika santrifüj edildi. Üst faz $1 \mathrm{ml}$ oluncaya kadar atıldı. Soğuk carnoy’s çözeltisi (3:1 oranında metanol ve glasiyel asetik asit) ile hacim 5 ml'ye tamamlandı. Oda sıcaklığında 20 dakika bekletildi. 1. fiksasyon tamamlandı. İşlem $2 \mathrm{kez}$ tekrarlandı. Son aşamada $1 \mathrm{ml}$ üst faz bırakıldı. Hücre süspansiyonu önceden deterjanla yıkanmış temiz lamlara damlatılarak yayıldı. Lamlar 1şıktan korunarak kurutuldu. Lamlar kuruduktan sonra May-Grünwald Giemsa (Sigma) ile boyandı. Her kan numunesine karşılık gelen lamlarda 1000 adet çift çekirdekli hücre içindeki mikroçekirdekler sayıldı. Proliferasyon indeksini (CBPI) bulmak amacıyla bir çekirdekli (MI), iki çekirdekli (MII), üç çekirdekli (MIII) ve dört çekirdekli (MIV) hücreler toplam 500 hücre olacak şekilde sayıldı.

$$
\mathrm{CBPI}=\mathrm{MI}+2(\mathrm{MII})+3(\mathrm{MIII}+\mathrm{MIV}) / 500 \text { formülüne göre CBPI hesaplandı. }
$$

\section{İstatistiksel Analiz}

KKD, MÇ ve proliferasyon indeksi değerleri arasındaki önem kontrolünün yapılmasında, sırası ile Mann-Whitney U testi, $\chi^{2}$ testi ve Student- $t$ testi kullanılmıştır. Sonuçlar ortalama değer \pm standart sapma olarak değerlendirilmiştir. Analizler microsoft office excel 2003 ve SPSS for Windows 11 programları kullanılarak yapılmıştır. 


\section{SONUÇ VE TARTIŞMA}

Yapmış olduğumuz çalışmada içme ve kullanma suları $(1,55$ - 20,8 mg/l) yolu ile normalin üzerinde bora maruz kalan kişilerin periferal kan lenfositlerindeki KKD ve MÇ sayıları tespit edilmiştir (Toplanan kişi sayısı 38'dir ancak değerlendirmeye alınan kişi sayısı bazı kan nümunelerinin kullanılamamış olması nedeni ile KKD için 35, MÇ için 37'dir). Bu değerler, içme ve kullanma sularında düşük oranda bor içeren yörelerde $(0,07-0,2 \mathrm{mg} / \mathrm{l})$ yaşayan bireyler arasından seçilen kontrol grubu ile karşılaştırılarak değerlendirilmiştir. (Bu yörelerden toplanan kişi sayısı 38 olup 1 nümunenin kullanılamamış olması nedeniyle değerlendirmeye alınan kişi sayısı KKD için 37, MÇ için 37'dir). KKD testinde maruz ve kontrol grubuna ait PRI değerleri sırası ile 1,87 ve 1,77 olarak tespit edilmiş ve aralarında istatistiksel olarak anlamlı bir fark bulunamamıştır ( $>>0,05$, Student $t$-test). MÇ yöntemin uygulanması esnasında, maruz ve kontrol grubuna ait CBPI değerleri sırası ile 1,36 ve 1,19 olarak tespit edilmiştir ve aralarında istatistiksel olarak anlamlı bir fark bulunamamıştır ( $>0,05$, Student $t$-test). Kontrol ve maruziyet grupları için tespit edilen PRI ve CBPI değerlerinin farklı olmaması, kontrol ve maruziyet grubunun kan nümuneleri için uygulanan deney koşullarının eşdeğer olduğunu göstermektedir.

Bora maruz kalan gruba ait kan nümuneleri $(n=35)$ ile kontrol grubuna ait kan nümuneleri $(n=37)$ için tespit edilen ortalama $\mathrm{KKD} /$ Hücre değerleri sırası ile 7,28 $\pm 1,60$ ve 9,50 $\pm 1,83$ 'tür. Maruz grup ve kontrol grubun ortalama KKD/Hücre değerleri arasındaki fark istatistiksel olarak anlamlı bulunmuştur (Mann-Whitney U-test, $\mathrm{p}<0,05$ ). Kontrol grubunun ortalama KKD/Hücre değerleri, maruz gruba göre daha yüksektir (Şekil 1).

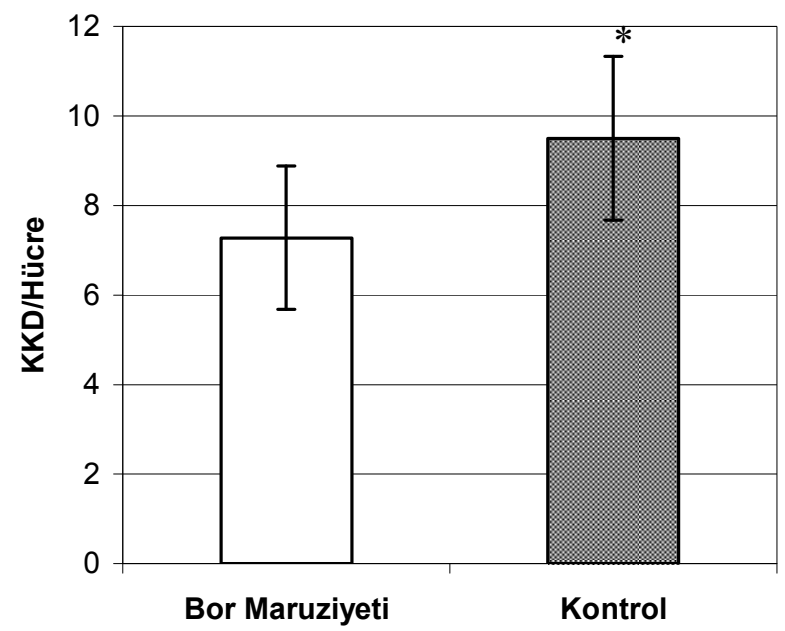

Şekil 1. Maruz kalan grup ile kontrol grubunun ortalama KKD değerlerinin karşılaştırılması (Bora maruz kalan grup ile kontrol grubu arasındaki fark istatistiksel olarak anlamlıdır; *Mann-Whitney U-test, $\mathrm{p}<0,05$ ). 
Grupların MÇ değerlerine bakıldığında bora maruz kalan grup için tespit edilen $\mathrm{MÇ}$ değerleri 9,81 \pm 1,94 olarak kontrol grubu için ise 20,32 $\pm 3,98$ olarak tespit edilmiştir. Her iki grubun ortalama MÇ değerleri arasında istatistiksel olarak anlamlı bir fark bulunamamış olmasına rağmen kontrol grubunda gözlenen ortalama MÇ değeri, bora maruz kalan gruptan elde edilen ortalama MÇ değerinden daha yüksektir (Şekil 2).

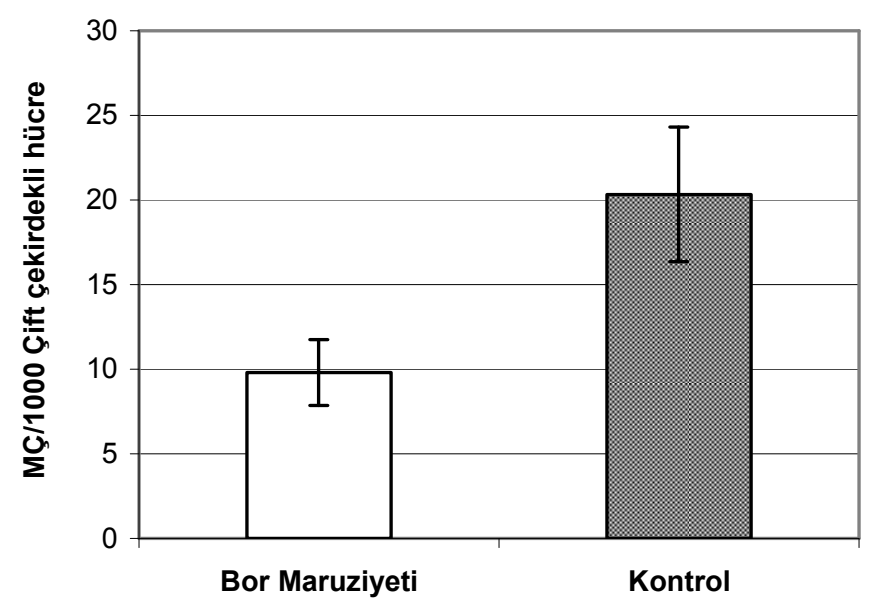

Şekil 2. Maruz kalan grup ile kontrol grubun ortalama MÇ değerlerinin karşılaştırılması. ( $p>0,05$,

$$
\chi^{2} \text { test). }
$$

Çalışmamızda yer alan bireyler arasındaki cinsiyet farkının, yaş farkının, sigara kullanımı ve ilaç kullanımının, elde edilen ortalama KKD ve MÇ değerleri üzerinde etkili olup olmadığı da araştırılmıştır. Ancak bu faktörlerin, bu çalışma için seçilmiş olan bireylerde gözlenen ortalama KKD ve MÇ değerleri üzerine olan etkilerinin istatistiksel olarak anlamlı olmadığı gözlenmiştir. Buna göre, bora maruz kalan kişilerden elde edilen ortalama KKD ve MÇ değerlerinin kontrol grubuna göre düşük olmasının yukarıda incelenen faktörlerden kaynaklanmadığı sonucuna ulaşılmaktadır. Yapılmış olan bu istatistiksel değerlendirmeler, içme sularında yüksek oranda bor içeren bölgelerde yaşayanlarda gözlenen daha düşük KKD ve MÇ ortalamalarının bor maruziyetinden kaynaklandığı ihtimalini güçlendirmektedir. Elde ettiğimiz sonuçlar doğrultusunda bora maruz kalan bireylerde gözlenen DNA hasarının daha düşük olduğunu söylemek mümkündür. $\mathrm{Bu}$ durumda borun oluşabilecek DNA hasarlarına karşı koruyucu bir etkisinin olabileceği söylenebilir. Bugüne kadar yapılmış olan çalı̧malar böyle bir ihtimali güçlendirmektedir. Özellikle bor maruziyetinin "Glukoz 6 Fosfat Dehidrogenaz" aktivitesini arttırdığı ve sonuçta NADPH oluşumunu indüklediği, sıçanlarda yapılan deneylerde gösterilmiştir. Buna bağlı olarak hücrelerde glutatyon (GSH) miktarının artması, hücreleri oksijen radikallerinin zararlı etkilerine karşı 
koruyabilmektedir $(7,18)$. Hücrelerde indirgenmiş ve yükseltgenmiş glutatyon (GSH/GSSG) oranın düşük olmasının, hücreleri oksijen radikallerinin oluşturabilecekleri hasarlara karşı daha duyarlı hale getirdiği bilinmektedir (19). Buna bağlı olarak herhangi bir ksenobiyotik maruziyeti sonrasında hücrede lipit peroksidasyonunun başlaması ve oksidatif DNA hasarının meydana gelmesi ihtimali artmaktadır. Konu bu yönü ile ele alındığında, bor maruziyetinin hücre içinde GSH düzeyini yükseltebileceği ve buna bağl1 olarak hücrelerde ksenobiyotik maruziyeti sonrasında oluşabilecek oksijen radikallerinin, lipit peroksidasyonunu veya oksidatif DNA hasarını indüklemesini önleyebileceği düşünülebilir. Buna göre yapmış olduğumuz çalışmada bora maruz kalan bireylerde görülen $\mathrm{KKD}$ ve $\mathrm{MÇ}$ değerlerinin kontrol grubuna göre düşük olması, borun hücrelerdeki GSH düzeylerini arttırabilmesinden kaynaklanmış olabileceği şeklinde yorumlanabilir. Bundan dolayı ksenobiyotik maruziyet sonucunda genotoksik etkilere karşı borun koruyucu bir etkisinin olduğu düşünülebilir. Ancak bu konuda daha ileri çalışmalara ihtiyaç bulunmaktadır.

Öte yandan bu çalışmanın kontrol grubundan elde edilen ortalama KKD ve MÇ değerleri, daha önce yapmış olduğumuz farklı çalışmalardaki kontrol grubu ortalamalarından yüksektir. Dolayısıyla bu çalışmada kontrol grubu olarak seçilen bireylerin yaşadıkları bölge itibariyle genotoksik etkili başka bir kimyasal maddeye de maruz kalmış olabilecekleri olmaları göz önünde bulundurulmalıdır. Buna bağlı olarak bora maruz kalan bireyler de aynı genotoksik kimyasal maddeye maruz kalıyor ise bu durumda borun genotoksik etkilere karşı koruyucu bir etkisinden söz etmek mümkün olabilecektir. Ancak bunun gösterilebilmesi için daha detaylı çalışmalara ihtiyaç vardir.

\section{KAYNAKLAR}

1. U.S. EPA., "Toxicology review of boron and compounds in support of summary information on integrated risk information (IRIS )". National Center for Environmental Assessment, Washington, sayfa 3, 12 (2004).

2. Çöl, M., Çöl, C. "Environmental boron contamination in waters of Hisarcık area in the Kütahya province of Turkey" Food Chem. Toxicol., 41, 1417 -1420 (2003).

3. Yazbeck, C., Kloppmann, W., Cottier, R., Sahuquillo, J., Debotte, G., Huel, G. "Health impact evaluation of boron in drinking water: a geographical risk assessment in Northern France" Environ. Geochem. Health, 27, 419 - 427 (2005). 
4. Murray, F.J., Andersen, M.E. "Data-derived uncertainty factors: Boric acid (BA) as a case study" Hum. Ecol. Risk Assess., 7(1), 125 -138 (2001).

5. EVGM (Expert Group on Vitamins and Minerals). "Revised review of boron" EVGM/99/23/P.REVISEDAU2002.

Erişim:

[http://www.food.gov.uk/multimedia/pdfs/boron.pdf]. Erişim tarihi: 16.06.2011.

6. Vaziri, N.D., Oveisi, F., Culver, B.D., Pahl, M.V., Andersen, M.E., Strong, P.L., Murray, F.J. "The effect of pregnancy on renal clearance of boron in rats given boric acid orally" Toxicol. Sci., 60, $257-263$ (2001).

7. Devirian, T.A., Volpe, S.L. "The physiological effects of dietary boron" Crit. Rev. Food Sci. Nutr., 43( 2 ), 219 -231 (2003).

8. Nielsen, F.H.. "Facts and fallacies about boron" Nutr. Today. 27, 6 -12 (1992).

9. Food and Nutrition Board, Washington, DC.: National Academy Press (2001).

10. IOM (Institute of Medicine). "Dietary reference intakes for vitamin A, vitamin K, arsenic, boron chromium, copper, iodine, iron, manganese, molybdenum, nickel, silicon, vanadium and zinc" Washington, DC: National Academy Press (2002).

11. Duydu, Y., Başaran, N., Üstündağ, A., Aydın, S., Ündeğer, Ü., Ataman, O.Y., Aydos, K., Düker, Y., Ickstadt, K., Waltrup, B.S., Golka, K., Bolt, H.M. "Reproductive toxicity parameters and biological monitoring in occupationally and environmentally boron-exposed persons in Bandirma, Turkey" Arch. Toxicol., 85, 589-600 (2011).

12. Szybalskı, W. "Special microbological system. II. Observations oon chemical mutagenesis in microorganisms" Ann. N. Y. Acad. Sci., 76, 475-489 (1958).

13. NTP (National Toxicology Program). Toxicology and carcinogenesis studies of boric acid ( CAS No. 10043 -35 -3 ) in B6C3F1 mice ( feed studies ). Public Health Service, U.S. Department of Health and Human Services, NTP TR - 324 (1987). Erişim:

[ http://ntp-server.niehs.nih.gov/htdocs/LT_rpts/tr324.pdf] ]. Erişim tarihi: 16.02.2006

14. Bakke, J.P. "Evaluation of the potential of boric acid to induce unscheduled DNA synthesis in the in vitro hepatocyte DNA repair assay using the male F-344 rat". Submitted by U.S. Borax Corp; MRID No. 42038903. [unpublished study] (1991). 
15. O'loughlın, K.G. "Bone marrow erthrocyte micronucleus assay of boric acid in Swicc Webster mice". Submitted by U.S. Borax Corp. MRID No. 42038904. [Unpublished data] (1991).

16. Korkmaz, M., Uzgören, E., Bakırdere, S., Aydın, F., Ataman, O.Y. "Effects of Dietary Boron on Cervical Cytopathology and on Micronucleus Frequency in Exfoliated Buccal Cells" Environ. Toxicol., 22, 17-25 (2007).

17. Perry, P., Wolff, S. "New Giemsa method fort he differential staining of sister chromatids" Nature, 258, 121-125 (1974).

18. Samman, S., Naghii, M.R., Lyons, W., Verus, A.P. "The nutritional and metabolic effects of boron in humans and animals" Biol. Trace Elem. Res., 66, 227 -235 (1998).

19. Ercal, N., Gürer-Orhan, H., Aykın-Burns, N. "Toxic metals and oxidative stress part I: mechanisms involved in metal-induced oxidative damage" Curr. Top. Med. Chem, 1(16), $529-539(2001)$. 